\title{
Single centre experience of double valve replacement using
}

\section{mechanical valves}

Saurabh KS ${ }^{1}$, Popli K², Chandrakumar SVPL ${ }^{3}$, Guroo SA ${ }^{4}$, Gupta A $^{5}$

1,3,4 Senior Resident, CTVS, VMMC \& SJH

2Assistant Professor, CTVS, VMMC \& SJH

5HOD, CTVS, VMMC \& SJH

*Corresponding Author - Popli K ,Department of Cardiothoracic and Vascular Surgery,VMMC and Safdarjung Hospital, New Delhi. DOI: 10.47799/pimr.0803.16

(C) 2020-21 Prathima Institue of Medical Sciences

\section{Abstract}

Introduction: Cardiac valvular disease in India is most commonly caused by Rheumatic aetiology, many of which end up getting operated for the same. There is still existing controversy about the selection of ideal valves that can be used for replacement.

Objective: Objective of this study was to retrospectively analyse the variable which can be easily assessed in the patients undergoing DVR (Double Valve replacement) using mechanical valves for its outcomes.

Methods: All the patients who underwent DVR + Tricuspid valve repair/annuloplasty between October 2017 to January 2019, were identified and retrospectively their data was analysed.

Results: 72 patients who underwent the procedure. Most common aetiology was Rheumatic. 69.4\% were in NYHA (New York Heart Association) class II, 33.33\% had chronic atrial fibrillation. $45.6 \%$ had associated tricuspid valve disease, and no chordae was preserved in $27.7 \%$. Overall mortality was $5.5 \%$

Conclusion: The study revealed a favourable survival outcome after DVR surgery. The operative mortality in patients undergoing DVR depends on intra operative factors like total surgical time, bypass time and aortic cross clamped time and has improved remarkably over time, with the improvisation of extracorporeal circulation methods, myocardial protection techniques and postoperative management.

Keywords: Double valve Replacement, Tricuspid valve repair, Patient Prosthesis mismatch

\section{INTRODUCTION}

It was in the 1960s that first double valve replacement was carried out, using first generation mechanical prosthesis.Up to mid-1970s, it was related with a high operative death ${ }^{[1-3]}$. The high profile first generations of valves, old cardiopulmonary bypass methods and flawedmyocardial protection were some of the major factors for dismal outcomes. With the introduction of second-generationmechanical low profile bi-leaflet mechanical valves, improvement in myocardial protection techniques enhancedthe short, medium, and long-term survival and prognosis inthe early 1980s. ${ }^{[4-6]}$
Rheumatic heart disease is one of the mostcommon cause of cardiac valvular disease, and inparticular in India the number is very significant.Most of the patients are in third decade oflife, butno age is exempt, except the first decade.Symptomatology may be gradual, or sudden onset. The natural history ofthe disease is also not well known though variesfrom individual to individual. The patients maypresent with stenotic or regurgitant lesions, or acombination of both, the disease mayaffect singleor multiple valves.

Many previous studies have compared the outcomes of double valve replacement (DVR) as per the implanted prosthesis,still there is existing controversy regarding selection of ideal heart valves in a patient undergoing DVR ${ }^{[7-9,11-13]}$. Some studies on DVR, along with the type of valves, have also studied the effects of pre-operative and intra-operative variables on the outcomes [3-5, 10-14]. The operative risk of DVR is stillbetween 5 and $13 \%$, whereas anisolated aortic valve replacement (AVR)the risk is less than $4 \%{ }^{[9,10]}$.

Pyrolytic carbon is used to manufacture St Jude Medical (ST Jude Medical Inc, St Paul, Minn) bi-leaflet valve, which was introduced in 1977 and got FDA approval in 1982. Its central flow design offers low transvalvular gradient, and pyrolytic carbon is used to make it durable and resistant to thrombus. These attributes have been verified in studies which have used this valve ${ }^{[5,16-23]}$.

\section{Material and methods:}

Retrospectively we analysed the data of all the patients who underwent Double Valve Replacement + Tricuspid valve repair/ annuloplasty. We take into account all the patients from October 2017 to January 2019, who underwent the abovementioned procedure on an elective basis after complete preoperative workup.

The patients who were excluded were -

1. Any patient undergoing concomitant Coronary artery bypass grafting - 04 cases

2. Any patient undergoing emergency valve surgery - 06 cases

3. Any patient who received Bioprosthetic Valve as replacement -12 cases

4. Any patient who had mitral valve repair coupled with aortic valve replacement - 02 cases 
5. Any patient who underwent concomitant aortic root enlargement- 07 cases

At our institute, the following mechanical prosthesis were used in the patients who are included in the study -

1. For mitral valve replacement -

a. St Jude Medical Masters Series Mechanical Heart Valve (sizes $25 \mathrm{~mm}$ to $33 \mathrm{~mm}$ )

2. For Aortic valve replacement -

a. St Jude Medical Regent Mechanical Heart Valve (sizes $17 \mathrm{~mm}$ to $25 \mathrm{~mm}$ )

3. For Tricuspid Valve Annuloplasty -

a. Medtronic Contour 3D 690R Annuloplasty Ring - Tricuspid Operative Procedure -

All patients underwent DVR + TV repair(double valve replacement + tricuspid valve repair) under standard cardiopulmonary bypass. Myocardial protection was accomplished by the collective institution of moderate hypothermia, topical cooling of myocardium with ice slush and ostial perfusion of the coronaries after aortotomy with potassium cardioplegia. At our institute most commonly used cardioplegia solutions are Del Nido and Custodial, as per the surgeon's preference. The valve replacement was done as per the usual protocols using Teflon pledgeted sutures. All the mitral valves and aortic valves were put as per the minimum size as advocated by matching patient's body surface area to the charts having Effective Orifice Area (EOA) of the St Jude Mechanical prosthesis, to avoid any incidence of patient prosthesis mismatch (PPM). Intra-operative and post-operative operative blood transfusions, inotropic requirements, time on ventilatory support varied on per patient basis as per requirement.

Immediate post-operative complications occurring within 10 days of the surgery were taken into account and included reexploration, low cardiac output syndrome, transfusion related acute lung injury, refractory arrythmias, acute renal failure, evidence of cerebrovascular incident, stuck valve (prosthetic valve thrombosis), sepsis and death.

The anticoagulation regime consisted of giving patient warfarin loading dose followed by titration of the dose to maintain the international normalized ratio (INR) between 2.5-3.5.

Routine post-operative 2D echo was done in all the patients on Post-operative day 1 and then as and when required.

\section{Results :}

There were total of 72 patients who were included in the study with 46 males (63.8\%) and 26 females (36.2\%). The average age amongst males was 33 years while amongst female it was 32 years. The other demographic details are evaluated in Table 1. Out of 72 , aetiology of 70 cases was Rheumatic heart disease while there was one case of degenerative valvular disease while the other one was having Marfan's Syndrome. There were 3 cases who underwent Percutaneous trans-septal mitral commissurotomy before they had to undergo Double valve replacement, while there were 4 cases who had an operative history of Closed Mitral Valvotomy, with a scar mark on the left 5 th intercostal space.

$69.4 \%$ of the patients were NYHA class II, $27.7 \%$ patients were NYHA class III, and $2.70 \%$ patients were NYHA class IV. $33.33 \%$ patients were pre-operatively having Atrial fibrillation while $66.66 \%$ patients were in Normal sinus rhythm. LA clot was present in $8.33 \%$ of patients, while $2.77 \%$ of them had a history of Cerebrovascular accident and were on anti-epileptic drugs. $11.11 \%$ patients were admitted with congestive cardiac failure, and were first stabilised using diuretics and inotropic supports and then were posted for surgery. $8.3 \%$ patients were diabetic while $16.6 \%$ patients were hypertensive. There was one case having infective endocarditis (Table 2). Left ventricular ejection fraction of $20-40 \%$ was in $6.94 \%$ of patients, $87.5 \%$ patients had left ventricular ejection fraction of $40-60 \%$ while $5.55 \%$ patients had left ventricular ejection fraction of $>60 \%$.

The valve lesions consisted of stenotic, regurgitant and mixed type in both aortic and mitral valve, while tricuspid valve mainly had regurgitation as the lesions. $26.3 \%$ patients had mitral regurgitation, $31.9 \%$ had stenotic mitral valve while $41.8 \%$ had mixed type of lesion. Meanwhile $48.6 \%$ of patients had aortic regurgitation, only $5.5 \%$ had pure stenotic lesions while $45.8 \%$ had mixed type of lesions (Table 3 ). The severity of tricuspid valve regurgitation is summarised in Table $4.61 .1 \%$ had no evidence of pulmonary arterial hypertension (PAH), 5.5\% had mild PAH, $23.6 \%$ had moderate PAH while $9.7 \%$ had severe $\mathrm{PAH}$. Those patients having severe pulmonary hypertension were started on Sildenafil (dose as per weight) post-operatively. Among the intra-operative parameters, the average aortic cross clamp time was 169.04 minutes while average total cardiopulmonary bypass time was 213.84 minutes. $5.55 \%$ patients underwent left atrial reduction plasty along with double valve replacement. $37.50 \%$ patients had total chordal preservation using various techniques while $34.72 \%$ patients had posterior chordal preservation. In $27.77 \%$ patients, chordae could not be preserved due to the severity of the disease. The different sizes of valves put in the patients are summarised in Table 5, 6 and 7. The most common size of mitral valve implanted was $29 \mathrm{~mm}$ while $19 \mathrm{~mm}$ was the most common aortic valve which was implanted. It is to be noted that tricuspid repair was done using annuloplasty rings while one patient each underwent De Vega annuloplasty and Commissurotomy respectively.

The overall mortality was $5.55 \%$ of total patients. $2.77 \%$ patients had transfusion related acute lung injury as cause of death while one patient each was lost due to acute kidney injury and sepsis respectively. We could successfully manage the cases of low cardiac output syndrome patients in the postoperative settings as per standard protocols and all of them 
eventually recovered. 11 patients had refractory arrythmias, and all of them had pre-operative atrial fibrillation. The rate was then controlled by the combination of beta blockers, calcium channel blockers and amiodarone, on per patient basis. There were no reported cases of prosthetic valve thrombosis while one patient had post-operative cerebrovascular accident which was managed conservatively (Table 8).

Demographic Details - (Table 1)

\begin{tabular}{|c|c|c|}
\hline Parameter & Male & Female \\
\hline Average Age & 33 years & 32 years \\
\hline Average weight & $49.57 \mathrm{~kg}$ & $49.8 \mathrm{~kg}$ \\
\hline Average Height & $158.46 \mathrm{~cm}$ & $155.34 \mathrm{~cm}$ \\
\hline Average BSA (Body surface area) & 1.48 & 1.46 \\
\hline Minimum Age & 14 years & 18 years \\
\hline
\end{tabular}

Other Parameters - (Table 2)

\begin{tabular}{|c|c|c|}
\hline & Total & $\begin{array}{c}\% \text { OF TOTAL } \\
\text { PATIENTS }\end{array}$ \\
\hline LA/LAA Clear & 66 & 91.6 \\
\hline LA/LAA Clot & 06 & 8.33 \\
\hline History of CVA & 02 & 2.77 \\
\hline CCF & 08 & 11.11 \\
\hline Diabetes Mellitus & 06 & 8.33 \\
\hline Hypertension & 12 & 16.66 \\
\hline Infective endocarditis (active) & 01 & 1.38 \\
\hline
\end{tabular}

LA - left atrium, LAA- left atrial appendage, CVAcerebrovascular accident

CCF- congestive cardiac failure

Characteristic of valve lesions: - (Table 3)

\begin{tabular}{|c|c|c|}
\hline $\begin{array}{c}\text { TYPE OF LESION IN } \\
\text { MITRAL VALVE }\end{array}$ & Total & $\begin{array}{c}\% \text { OF TOTAL } \\
\text { PATIENTS }\end{array}$ \\
\hline Regurgitation & 19 & 26.3 \\
\hline Stenosis & 23 & 31.9 \\
\hline Mixed & 30 & 41.8 \\
\hline TYPE OF LESION IN AORTIC VALVE & TOTAL & $\%$ OF TOTAL PATIENTS \\
\hline Regurgitation & 35 & 48.6 \\
\hline Stenosis & 04 & 5.5 \\
\hline Mixed & 33 & 45.8 \\
\hline
\end{tabular}

Associated Tricuspid Valve Disease: - (Table 4)

\begin{tabular}{|c|c|c|}
\hline & Total & $\begin{array}{c}\text { \% OF TOTAL } \\
\text { PATIENTS }\end{array}$ \\
\hline No Disease & 32 & 44.4 \\
\hline Mild Tricuspid Regurgitation & 13 & 18.05 \\
\hline Moderate Tricuspid Regurgitation & 14 & 19.4 \\
\hline Severe Tricuspid Regurgitation & 12 & 16.6 \\
\hline
\end{tabular}

Mitral Valve Size - (Table 5)

\begin{tabular}{|c|c|c|}
\hline Valve Size (in mm) & Total & $\begin{array}{c}\text { \% OF TOTAL } \\
\text { PATIENTS }\end{array}$ \\
\hline $25 \mathrm{~mm}$ & 06 & 8.33 \\
\hline $27 \mathrm{~mm}$ & 19 & 26.38 \\
\hline $29 \mathrm{~mm}$ & 33 & 45.83 \\
\hline $31 \mathrm{~mm}$ & 13 & 18.05 \\
\hline $33 \mathrm{~mm}$ & 01 & 1.38 \\
\hline
\end{tabular}

Aortic Valve Size - (Table 6)

\begin{tabular}{|c|c|c|}
\hline Valve Size (in mm) & Total & $\begin{array}{c}\text { \% OF TOTAL } \\
\text { PATIENTS }\end{array}$ \\
\hline 17 & 03 & 4.16 \\
\hline 19 & 30 & 41.66 \\
\hline 21 & 26 & 36.11 \\
\hline 23 & 09 & 12.50 \\
\hline 25 & 04 & 5.55 \\
\hline
\end{tabular}

Tricuspid Valve Intervention-(Table 7)

\begin{tabular}{|c|c|c|}
\hline & Total & $\begin{array}{c}\text { \% OF TOTAL } \\
\text { PATIENTS }\end{array}$ \\
\hline No Intervention & 53 & 73.61 \\
\hline De Vegas Annuloplasty & 01 & 1.38 \\
\hline Commissurotomy & 01 & 1.38 \\
\hline $26 \mathrm{~mm}$ ring & 01 & 1.38 \\
\hline $28 \mathrm{~mm}$ ring & 06 & 8.33 \\
\hline $30 \mathrm{~mm}$ ring & 06 & 8.33 \\
\hline $32 \mathrm{~mm}$ ring & 04 & 5.55 \\
\hline
\end{tabular}


Post-Operative complications - (Table 8)

\begin{tabular}{|l|c|c|c|}
\hline \multicolumn{1}{|c|}{ Complications } & $\begin{array}{c}\text { Number of } \\
\text { Patients }\end{array}$ & $\begin{array}{c}\text { Number of } \\
\text { Deaths }\end{array}$ & $\begin{array}{c}\% \text { of total } \\
\text { patients }\end{array}$ \\
\hline Re-Exploration & 05 & None & None \\
\hline LCOS & 13 & None & None \\
\hline TRALI & 04 & 02 & 2.77 \\
\hline AKI & 03 & 01 & 1.38 \\
\hline Refractory Arrythmias & 11 & None & None \\
\hline CVA & 01 & None & None \\
\hline $\begin{array}{l}\text { Prosthetic Valve } \\
\text { Thrombosis }\end{array}$ & None & None & None \\
\hline Sepsis & 04 & 01 & 1.38 \\
\hline
\end{tabular}

LCOS - Low cardiac output syndrome, TRALI - Transfusion related acute lung injury, AKI - Acute kidney injury, CVACerebrovascular accident

\section{Discussion}

The morbidity and mortality associated with double valve replacement (DVR) is one of the many challenges for a cardiac surgeon. In a developing country like India, the patients often present late to the tertiary centre for their treatment. This delay in starting the treatment often puts the patient at higher risk of morbidity and mortality post-surgery. Medical and surgical management of the patient with multiple valvular disease is according to severity of each valvular lesion and myocardial factors are also taken in account.

Cartwright et al firstreported concurrent aortic and mitral valvereplacement. ${ }^{[24]}$ Besides rheumatic heart disease, connective tissue disorders like Marfan's Syndrome may affect the annulus of more than one valve leading to varied lesions. Degenerative calcifications of aortic valve can be associated with mitral annular dilatation. Other pathological conditions like infective endocarditis and papillary muscle dysfunction due to ischaemia may be a cause of regurgitation in multiple valvular disease. ${ }^{[25]}$

Operative risk of DVR is about $50 \%$ higher thanthat for the single valve replacement, whichdue to advancement in modern technologies has shown a declining trend and it nowranges from 5 to $10 \%$.[26] 63\% survival rate forDVR equated to $80 \%$ for single valve has beenstated as early as 1993. ${ }^{[27]}$

The long-term survival depends on many patient demographic factors as discussed earlier, the time of presentation, NYHA class at the time of presentation and the duration of the disease. Intraoperative and postoperative factors like myocardial protection, aortic cross clamp time and total cardiopulmonary bypass time are directly or indirectly related to the morbidity and mortality of the patients. Also, the comorbidities of the patient play a significant role.
We must stress that the severity of combined valvularlesions must be addressed before decidinga specific form of therapy.Co-existing lesions can adverselycomplicate the surgery or alter theexpected post-operative recovery. ${ }^{[28,29]}$

Timing for surgical intervention in a patient having combined valvular disease is not defined yet.[30]Heart failure and sudden death are the foremost late causes of death. Heartfailure can occur in a subtle way, many years after valve replacement. The advent of newtreatment regimes, such as angiotensinconverting enzyme inhibitors (ACE inhibitors) or angiotensin II receptor blockers (ARB's), has led to long-term improvement ofsecondary left ventricular failure.

Pre-operative left ventricular ejection fraction(LVEF) is an important determinant of post-operativelong-term survival after DVR. The post-operative recovery after successful DVR is also limited when pre-operative LVEF is severely depressed. [31,32]

Peri-operative mortality in our study was $5.5 \%$. These resultscompare favourably with other long-term studies of thisprosthesis. ${ }^{[21-23]}$ Our data shows that preoperative patient characteristics such as age, previous valve replacement,cardiac function, and coronary disease may have agreater influence on operative mortality than the type ofvalve prosthesis implanted. Similar operative mortality is seen in other studies using various types of valves. ${ }^{[9,33-35]}$

Diseased tricuspid valve may cause chronically overloaded right ventricle which can become dilated and in post-operative state, biventricular failure may occur. Tricuspid valve repairshould be done when significant disease or regurgitationis present, because only correction of left sided disease will not eliminate the disease of right side. Though, this leads to increased duration of operation ${ }^{[37,38]}$. Many studies have shown that if LVEF is compromised in pre-operative state, potential for improvement after DVR is limited. ${ }^{[32,36,39]}$

Czer et al $^{[18]}$ described the actuarial survival rate at was $51 \%$ for AVR, 47\% for DVR, and 41\% for MVR after 9 years.Arom et al ${ }^{[5]}$ reported,which comprised of operative deaths, 9-year survival rate of $75.5 \%$ forAVR,73.8\% for DVR, and $57.7 \%$ for MVR. Their series consistedof patients who also required concomitant coronary artery bypass grafting.

The occurrence of thromboembolic and anticoagulantrelated haemorrhagedepends on the anticoagulant state. In most series, warfarin is used for anticoagulation. However, the method for testing the anticoagulantstate, theadequate range of warfarin control, or both, differ from institution to institution. At our institute we use INR (international normalised ratio) as the standard method for checking the anticoagulant state of the patient.

A patient having a mechanical valve who has suffered intracranial bleed, the role of anticoagulant, whether to continue or to stop during the treatment, baffles the treating doctor. However, the anticoagulation on which the patient is, 
can be withheld safely for 7-14 days if the patient has suffered intracranial bleed with low incidence of thromboembolic episode. Patient having prosthetic valves, anticoagulation in the form of heparin can be instituted as early as 3 days and can be switched back to oral anticoagulation on which the patient was, at 7 days, without any major concern for bleeding [40].

Long-term survival was significantly reliant on on the preoperative LVEF, as also shown byMueller et al [41]. Prolonged ventilation, ionotropic support and long ICU stay was seen more in patients with LVEF of less than $45 \%$. Mortality and morbidity being more in patients with low LVEF is well documented and observations in our study are comparable to others. [42-45]

Literature shows a prevalence of mitral regurgitation, trailed by aortic regurgitation. $[7,24]$ This study shows a higher prevalence of aortic regurgitation, followed by mixed mitral lesions, and only then mitral and aortic stenosis lesions.

Bioprosthetic valve is implanted in patients with contraindication to anticoagulation therapy, with reduced life expectancy, a woman who wishes to complete a family, in addition to the social indicator which specifies tough access to anticoagulant therapy. [24,43,44,45]

As per Bortolotti et al mechanical valvesare better in the long term due to their superior durability.[7]

There was not a single case of paravalvular leak in present study. It is said that the use of interrupted horizontal mattress sutures with Teflon pledgets play a majorpart in the prevention of paravalvular leak. Bortolotti et al stated an incidence of the same in $0.67 \pm 0.2 \%$ in a study of DVR using mechanical prostheses.[7] Sethia et al reported on a 14-year experience noting a high incidence of paravalvular leak ( $2 \%$ per year) and suggest that horizontal mattress sutures improve valve stability and may reduce this valve related complication, along with the fact that it also reduces the chance of ventricular rupture[46]

\section{Conclusion}

In summary, operative mortality for patients undergoing combined aortic and mitral valve replacement has decreased significantly over the past 10 years because of improvements in myocardial protection and other advances in perioperative care. Patients who are classified in higher NYHA grades, with hemodynamicaly significant aortic and mitral valvular lesions can be offered DVR with low operative risk and a significant chance for improvement in the quality of their lives. The survival of patients labelled pre-operatively as higher NYHA grade is probably better than that of patients who do not undergo surgery, even though this point is un-documented.

For patients with symptomatic cardiac failure, DVR is sometimes performed as a life-saving effort. Most of these patients are improved after surgery. In our study, the peri- operative risk factors and mortality is having comparable results with other studies. Good surgical technique and advancement in technology has significantly reduced the morbidity and mortality associated with DVR. Advancement in valve designs may further reduce the anti-coagulation related risk factors to the patients.

\section{Limitation of the study}

A possible limitation of the study is its retrospective character. Additional follow-up may be able to show the current status of all survivors in the near future

\section{REFERENCES}

1. Horstkotte D, Loogen F, Kleikamp G, Schulte HD, Trampisch $H J$, Bircks W. The influence of heart-valve replacement on the natural history of isolated mitral, aortic and multivalvular disease: clinical results in 783 patients up to 8 years after implantation of Björk-Shiley tilting-disc prostheses. Z Kardiol. 1983;72:494-503.

2. Stephenson LW, Edie RN, Harken AH, Edmunds LH. Combined aortic and mitral valve replacement: changes in practice and prognosis. Circulation. 1984;69:640-644.

3. Teoh KH, Christakis GT, Weisel RD, Tong CP, Mickleborough LL, Scully HE, Goldman BS, Baird RJ. The determinants of mortality and morbidity after multiple-valve operations. Ann Thorac Surg. 1987;43:353-360

4. Remadi J.P., Baron O., Bizouarn P., et al. Mitral valve replacement with the St. Jude Medical Prosthesis: a 15year follow-up. Ann Thorac Surg 1998; 66: 762-767.

5. Arom KV, Nicoloff DM, Kersten TE, Northrup WF, Lindsay WG, Emery RW. Ten-year follow-up study of patients who had double valve replacement with the St Jude Medical prosthesis. J Thorac Cardiovasc Surg. 1989;98:1008-1016.

6. Galloway $\mathrm{AC}$, Grossi $\mathrm{EA}, \mathrm{Baumann} \mathrm{FG}$, Lamendola $\mathrm{CL}$, Crooke GA, Harris LJ, Colvin SB, Spencer FC. Multiple valve operation for advanced valvular heart disease: results and risk factors in 513 patients. J Am Coll Cardiol. 1992;19: 725-732.

7. Bortolotti U, Milano A, Testolini L, Trusi V, Mazzucco A, Gallucci V. Influence of type of prosthesis on late results after combined mitral aortic valve replacement. Ann Thorac Surg 1995; 59: 1113-1119

8. Munro AL, Jamieson E, Burr LH, Ling H, Miyagishima RT, Germann E. Comparison of porcine bioprostheses and mechanical prostheses in multiple valve replacement operations. Ann Thorac Surg 1995; 60:459-463

9. Khan SS, Trento A, DeRobertis M. Twenty-year comparison of tissue and mechanical valve replacement. J Thorac Cardiovasc Surg 2001; 122: 257269 
10. Kuwaki K, Tsukamoto M, Komatsu K, Morishita K, Sakata J, Abe T. Simultaneous aortic and mitral valve replacement: predictors of adverse outcome. J Heart Valve Dis 2003; 12: 169-176

11. Armenti F, Stephenson LW, Edmunds LH. Simultaneous implantation of St. Jude Medical aortic and mitral prostheses. J Thorac Cardiovasc Surg 1987; 94: 733-739

12. Fiore AC, Swartz MT, Sharp T. Double-valve replacement with Medtronic Hall or St. Jude valve. Ann Thorac Surg 1995; 59: 1113-1119

13. Brown PS, Roberts CS, Mclntosh CL, Swain JA, Clark RE. Relation between choice of prostheses and late outcome in double-valve replacement.

Ann Thorac Surg 1993; 66: 631-640

14. Caus T, Rouviere P, Clooart F, Mouly-Bandini A, Monties JR, Mesana T. Late results of double-valve replacement with biological or mechanical prostheses. Ann Thorac Surg 2001 ; 71: 261-263

15. Crawford FA Jr, Kratz JM, Sade RM, Stroud MR, Bartles DM. Aortic and mitral valve replacement with the St Jude Medical prosthesis. AnnSurg. 1984;199:753-61.

16. Kratz JM, Crawford FA Jr, Sade RM, Crumbley AJ III, Stroud MR. St Jude prosthesis for aortic and mitral valve replacement: a ten year experience. Ann Thorac Surg. 1993;56:462-8.

17. Arom KV, Nicoloff DM, Kersten TE, Lindsay WG, Northrup WF III. St Jude Medical prosthesis: valve-related deaths and complications. Ann Thorac Surg. 1987;43:591-8.

18. Czer LS, Chaux A, Matloff JM, et al. Ten-year experience with the St Jude Medical valve for primary valve replacement. J Thorac CardiovascSurg. 1990;100:44-55.

19. Khan S, Chaux A, Matloff J, et al. The St Jude Medical valve. Experience with 1000 cases. J Thorac Cardiovasc Surg. 1994;108: 101020.

20. Zellner JL, Kratz JM, Crumbley AJ III, et al. Long-term experience with the St Jude Medical valve prosthesis. Ann Thorac Surg. 1999;68:1210-8.

21. Remadi JP, Baron O, Roussel C, et al. Isolated mitral valve replacement with St Jude Medical prosthesis: long-term results: a follow-up of 19 years. Circulation. 2001;103:1542-5.

22. Lund O, Nielsen SL, Arildsen H, Ilkjaer LB, Pilegaard HK. Standard aortic St Jude valve at 18 years: performance profile and determinants of outcome. Ann Thorac Surg. 2000;69:1459-65.

23. Emery RW, Arom KB, Kshettry VR, et al. Decision-making in the choice of heart valve for replacement in patients aged 60-70 years: twenty-year follow up of the St Jude
Medical aortic valve prosthesis. J Heart Valve Dis. 2002;11(Suppl 1):S37-44.

24. Cartwright RS, Giacobine JW, Rattan RS, Ford WB, polish WE. Combined aortic and mitral valve replacement. J Thorac Cardiovasc Surg, 1963; 45: 35-40.

25. Braunwald. Multivalvular heart disease, In; text Book of cardiovascular medicine. A prism Indian, 5th edn. 1997; 2: 1060-61.

26. Nicoloff DM, Emery RW, Arom KV. Clinical and hemodynamic results with St. Jude Medical Cardiac Valve prosthesis. J Thorac Cardiovasc Surg, 1981; 82: 674- 683.

27. Kirklin JW, Barratt Boyes BG. Combined aortic and mitral valve disease with or with out tricuspid valve disease. In: cardiac Surgery 2nd edn. New York: Churchillivingstone 1993: 573-88.

28. Segal J, Harvey WP, Hufnagal CA. Clinical study of one hundred cases of severe aortic insufficiency. Am J Med 1956; 21: 200.

29. Zitnik RS. The masking of aortic stenosis by mitral stenosis. Am Heart J 1965; 69:22.

30. Bonow RO, Carabello B, de Leon AC Jr, Edmunds LH Jr, Fedderly BJ, Freed MD, Gaasch WH, McKay CR, Nishimura RA, O’Gara PT, O’Rourke RA, Rahimtoola SH. ACC/AHA guidelines for the management of patients with valvular heart disease: a report of the American College of Cardiology/American Heart Association Task Force on Practice Guidelines (Committee on Management of Patients With Valvular Heart Disease). J Am Coll Cardiol. 1998; 32:1486-1588.

31. Borow KM, Green LH, Mann T, Sloss LJ, Braunwald E, Collins JL, Cohn L, Grossman W. End systolic volume as a predictor of postoperative left ventricular performance in volume overload from valvular regurgitation. Am J Med. 1980;68:655-663.

32. Turina J, Milincic J, Seifert B, Turina M. Valve replacement in chronic aortic regurgitation: true predictors of survival after extended follow-up. Circulation. 1998;98(suppl II):II100-II-107.

33. Masters RG, Helou J, Pipe AL, Keon WJ. Comparative clinical outcomes with St Jude Medical, Medtronic Hall and CarboMedics mechanical heart valves. J Heart Valve Dis. 2001;10:403-9.

34. Butchart EG, Li HH, Payne N, Buchan K, Grunkemeier GL. Twenty years' experience with the Medtronic Hall valve. J Thorac CardiovascSurg. 2001;121:1090-100.

35. Anttila $\mathrm{V}$, Heikkinen J, Biancari $\mathrm{F}$, et al. A retrospective comparative study of aortic valve replacement with $\mathrm{St}$ Jude medical and Medtronic- Hall prostheses: a 20-year follow-up study. Scand Cardiovasc J. 2002;36:53-9 
36. Turina J, Stark T, Seifert B, Turina M. Predictors of the longterm outcome after combined aortic and mitral valve surgery. Circul 1999; 100 (Suppl 2): 48-53

37 Simon R, Oelert H, Borst HG, Lichtlen P. Influence of mitral valve surgery on tricuspid incompetence concomitant with mitral valve disease. Circul 1980; 62: 1152-1157

38. King RM, Schaff HV, Danielson GK, Gersh BJ, Orszulak TA, Pichler JM, Puga FJ, Pluth JR. Surgery for tricuspid regurgitation late after mitral valve replacement. Circul 1984; 70 (Suppl 2): 193-197

39. Cohn LH, Couper GS, Aranki SF, Rizzo RJ, Kinchla NM, Collins JJ. Longterm results of mitral valve reconstruction for regurgitation of the myxomatous mitral valve. J Thorac Cardiovasc Surg 1994; 107: 143-151

40. Chandra D, Gupta A, Grover V, Kumar Gupta V. When should you restart anticoagulation in patients who suffer an intracranial bleed who also have a prosthetic valve?. Interact Cardiovasc Thorac Surg. 2013;16(4):520-523. doi:10.1093/icvts/ivs545

41. Bernal JM, Rabasa JM, Gutierrez-Garcia F, Morales C, Nistal J, Revuelta JM. The CarboMedics valve: experience with 1,049 implants. Ann Thorac Surg. 1998;65:137-43.

42. Schaff HV, Marsh DH. Multiple valve disease. In: Cohn LH, ed. Cardiac surgery in the adult. 2nd edition. McGrawHill; USA: 2003:425-4302.

43. Jamieson WR, Edwards FH, Schwartz, M, Bero JW, Clark $\mathrm{RE}$, Grover FL. Risk stratification for valve replacement. National Cardiac Surgery Database. Database Committee of The Society of Thoracic Surgeons. Ann Thorac Surg. 1999;67(4):943-51.

44. Litmathe J, Boeken U, Kurt M, Feindt P, Gams E. Predictive risk factors in double-valve replacement (AVR and MVR) compared to isolated aortic valve replacement. Thorac Cardiovasc Surg. 2006;54:459-63.

45. Karp RB, Cyrus RJ, Blackstone EH, Kirklin JW, Kouchoukos NT, Pacifico AD. The Björk-Shiley valve: intermediate-term follow-up. J Thorac Cardiovasc Surg. 1981;81:602-14.

46. Sethia B, Turner MA, Lewis S, Rodger RA, Bain WH. Fourteen years experience with the Björk-Shiley tilting disc prosthesis. J Thorac Cardiovasc Surg. 1986;91:350-6

How to cite this article : Saurabh KS, Popli K, Chandrakumar SVPL, Guroo SA, Gupta A. Single centre experience of double valve replacement using mechanical valves. Perspectives in Medical Research 2020; 8 (3):74-80

DOI: $10.47799 /$ pimr.0803.16

Sources of Support: Nil, Conflict of interest: None declared 